\title{
Francisco Xavier de Lizana y Beaumont. El discurso ideológico de un arzobispo-virrey en México, 1803-1810
}

\section{Francisco Xavier de Lizana and Beaumont. The ideological discourse of an archbishop-viceroy in Mexico, 1803-1810}

\author{
DOI:10.25100/hye.v17i56.11228
}

Artículo recibido: 3-10-2019. Artículo aceptado: 16-6-2020

\begin{abstract}
Alfonso Rubio
Profesor Titular

Departamento de Historia/Facultad de Humanidades

Universidad del Valle (Cali, Colombia)

Correo electrónico: alfonso.rubio@correounivalle.edu.co

ORCID: https://orcid.org/0000-0002-5782-5092
\end{abstract}

Forma de citar este artículo: Rubio, Alfonso. "Francisco Xavier de Lizana y Beaumont. El discurso ideológico de un arzobispo-virrey en México, 1803-1810”. Historia y Espacio, vol. 17, nº 56 (2021): 45-82. Doi. org/ 10.25100/hye.v17i56. 11228

Artículo Tipo: Investigación

(cC) BY-NC-SA Esta obra está publicada bajo la licencia CC Reconocimiento- No Comercial - Compartir Igual 4.0 


\section{Resumen}

Francisco Xavier de Lizana y Beaumont nació el 13 de diciembre de 1749 en la ciudad de Arnedo, en la actual Comunidad Autónoma de La Rioja (España). Después de su carrera eclesiástica en España, es nombrado arzobispo de México en enero de 1803 , y entre 1809 y 1810 , durante diez meses, llegó a ser virrey de la Nueva España. Fue conocido por sus cualidades como escritor y predicador de sermones y cartas pastorales, y es nuestro propósito aquí analizar sus discursos impresos, que se dieron a conocer en México, desde una selección significativa de los mismos para interpretar su contenido ideológico y moral en un contexto político de crisis para la Corona española.

Palabras clave: Francisco Xavier de Lizana y Beaumont, arzobispo-virrey, Nueva España, cartas pastorales, comienzos del siglo XIX

\section{Abstract}

Francisco Xavier de Lizana and Beaumont was born on December 3, 1750 in Arnedo, the current Autonomous Community of La Rioja (Spain). After his ecclesiastical career in Spain, he was appointed Archbishop of Mexico in January 1803 and he became Viceroy of New Spain during ten months between 1809 and 1810. He was known for his qualities as a writer, preacher of sermons and pastoral letters. The purpose of this article is to analyze his printed discourses known in Mexico from a significant selection of them in order to interpret their ideological and moral content in a political context of crisis for the Spanish Crown.

Keywords: Francisco Xavier de Lizana y Beaumont, Archbishop-Viceroy, New Spain, pastoral letters, early 19 th century. 


\section{Francisco Xavier de Lizana y Beaumont. El discurso ideológico de un arzobispo-virrey en México, 1803-1810}

\section{Introducción}

El día 11 de enero de 1803, entre un "numeroso pueblo" que, en coches, a caballo y a pie, ocupaba las calles y las plazas de la Ciudad de México, y en medio del "general repique de campanas" y las entusiastas aclamaciones de una "Grey religiosísima" que veía en su rostro "las prendas amables" que le caracterizan, el nuevo Arzobispo llegó al Palacio Real, donde hizo su primera visita al Excelentísimo Señor Virrey. Concluida esta, pasó a su Palacio Arzobispal, en cuya puerta fue recibido por el Cabildo y la Curia Eclesiástica con la solemnidad acostumbrada.

Durante este día y el siguiente, en su homenaje "hubo espléndidos" banquetes y refrescos para las personas más distinguidas" de la ciudad. El día 29 del mismo mes, a las once de la mañana se anunció por bando público la "solemne posesión" que el domingo inmediato debía tomar en su Santa Iglesia el Ilustrísimo Prelado. A las cuatro de la tarde salió la "Excelentísima Ciudad de sus Casas Consistoriales" precedida de timbaleros, ministros de justicia, dos tenientes de alguacil mayor, músicos y meseros, todos ellos a caballo. A continuación, en coches de tiros largos, los caballeros regidores $\mathrm{y}$ alcaldes ordinarios.

Encaminándose al Palacio Arzobispal se incorporó Su Ilustrísima, “acompañándole al vidrio el Regidor Alcalde Ordinario de primer voto", el Corregidor en turno y el Regidor Decano, precediendo al coche el Crucero de Su Ilustrísima. Desde ahí, desfilando por las principales calles de la ciudad, llegaron a la puerta de la Catedral, donde el Cabildo Eclesiástico recibió al prelado y lo condujo a la Sala Capitular. Leídas las Bulas y Cédulas Reales, Su Ilustrísima hizo la protesta de fe y el juramento que contemplan los estatutos de la Santa Iglesia, prestando a continuación la solemne obediencia a los señores capitulares. Los abrazó uno por uno y "revestido de capa magna”, precedido del clero, se encaminó por el presbiterio al coro. Acomodado en él junto a los miembros del cabildo eclesiástico y el secular, el secretario leyó en alta voz la Bula y la Real Cédula que los señores Deán, 
Corregidor y Decano de la Ciudad de México besaron y pusieron sobre su cabeza en señal de obediencia.

Su Ilustrísima y estas dignidades ocuparon después las sillas altas del coro, manteniéndose abajo los representantes de ambos cabildos. El Prelado cantó la oración de la Asunción de Nuestra Señora, titular de la Catedral y, concluida, la "capilla de música" entonó durante un cuarto de hora un villancico con toda la orquesta, volviendo luego a tocar todas las campanas de la ciudad hasta que el ya nombrado Arzobispo regresó a su Palacio. La comitiva volvió del coro al presbiterio, donde el Secretario del Cabildo subió al "Ambón de la Epístola" y leyó las Bulas de su Santidad dirigidas al clero, a la ciudad y a los vasallos de México. Concluida su lectura, el "señor provisor" besó la primera en nombre del clero, el "caballero corregidor" la segunda por la ciudad, y el "pertiguero" la tercera en representación del pueblo.

Seguidamente se entonó el Te Deum y se cantó durante la procesión por los pasillos de la iglesia, concluyéndose con la oración y bendición que el Señor Arzobispo dio al pueblo. Alas siete de la noche, "desnudándose de los pontificales y vestido de muceta" regresó con el mismo acompañamiento, alumbrando con hachas de cera "tan excesivos [...] gentío y concurrencia" de las calles, "que se cree no haberse visto jamás mayor en esta capital"2.

El numeroso gentío y el ornato que rodean este nombramiento del arzobispo en la Ciudad de México indican que es una celebración que se inscribe dentro de unas formas dominantes de sociabilidad que abarcaban por lo común a todos los grupos sociales y en las cuales los actos de carácter religioso (misas, procesiones, aclamaciones, fiestas) hacen difícil pensar en una "esfera civil" claramente diferenciada del mundo cultural que promovían y controlaban las instituciones eclesiásticas. Grupos de una sociedad colonial que socioculturalmente estaba más integrada de lo que normalmente pensamos, sin excluir la heterogeneidad, la diferencia ni las jerarquías, en las que la Iglesia y los hombres de iglesia jugaban un papel principal para la clasificación de los actores sociales ${ }^{3}$.

1 Las "negritas" en todo el texto son nuestras. Subrayan ideas principales dentro de la argumentación

2 Gaceta de México, 11 de febrero de 1803, 234-237.

3 Renán Silva, "El sermón como forma de comunicación y como estrategia de movilización. Nuevo Reino de Granada a principio del siglo XVII”, Sociedad y Economía, n.o 1 (2001): 109,130 . 
El riguroso protocolo que exige la entrada del futuro arzobispo en la Ciudad de México y la celebración de la toma de posesión de su cargo demuestran, cinco años antes del comienzo de los sucesos preindependentistas, el rígido orden estatal que todavía se mantenía, la simbiosis de los poderes eclesiásticos con los civiles y la obediencia que se debía a sus dos máximos representantes: el papa y el rey. El acto simbólico de la posesión del cargo utilizaba tres elementos que fueron constantes en la representación de este tipo de ceremonias con pretensiones de obediencia a las autoridades y de mantener un determinado orden social: el anuncio previo del acto a celebrar mediante pregón oral y bando escrito por las calles de la ciudad para movilizar a la población; el decoro con que se revestía y el juramento a ciertos tipos documentales de máxima solemnidad, como en este caso las bulas papales y las Cédulas reales.

La lectura pública en voz alta del contenido de los documentos y el ritual de su juramento, besándolos y poniéndolos sobre la cabeza de quienes debían obedecerlos, muestran la eficacia simbólica que el documento escrito poseía en el gobierno institucional ${ }^{4}$. La misma eficacia que el sermón o la carta pastoral mantuvieron, bien a través de su prédica pública ante los distintos grupos de la sociedad colonial, bien a través de su lectura, que por medio de la imprenta podían alcanzar a los sectores alfabetizados. El prestigio de quien puede escribir y predicar un sermón le viene de su dominio de la oratoria sagrada y de la estrecha relación entre su palabra y la verdad que ante los fieles se establece. El predicador es un nexo entre la religión y las comunidades e individuos particulares, que a través de su discurso puede recrear y actualizar el Evangelio para dar argumentos concretos buscando soluciones a cuestiones sociales del momento.

Pero, ¿quién es este nuevo arzobispo que, como tal, debe predicar la palabra evangélica a sus ministros eclesiásticos y a los fieles que ocupan su jurisdicción asignada? Se trata de Francisco Xavier de Lizana y Beaumont, quien antes de llegar a México, ya era conocido por la fama de sus discursos públicos. La prédica y las actuaciones de Lizana, quien llegó a ser virrey de la Nueva España durante diez meses, fueron un buen ejemplo entre la élite eclesiástica de la Corona española, y el elogio fúnebre que José María de Alcalá y Orozco, canónigo magistral de la catedral de la Ciudad de México, dedicó al arzobispo, lo alaba de tal manera que evidencia que fueron ciertas sus cualidades como

4 Alfonso Rubio, La escritura del archivo. Recurso simbólico y poder práctico en el Nuevo Reino de Granada (Santiago de Cali: Universidad del Valle/Facultad de Humanidades/Departamento de Historia, 2014), 117-128. 
escritor de oratoria sagrada y su proclamación pública. La traducción del latín al castellano del elogio indica, además, la voluntad doble de honrar al "ilustre muerto" llegando a una mayoría de público, y de influir sobre él, no solo sobre los letrados que comprendían el latín.

El corpus de sus discursos que, en forma de carta pastoral, sermón, exhortación o proclama, hemos elegido para analizar su contenido ideológico y moral, así lo pone de manifiesto. Fue un perfecto conocedor de las técnicas o reglas compositivas y estilísticas de la oratoria y sus resultados demuestran una producción prolífica que nunca hizo desmejorar su calidad literaria. Sermones y, fundamentalmente, cartas pastorales, las seleccionadas, que se encuentran impresas y dispersas entre los fondos documentales de la Biblioteca y Hemeroteca Nacional de México; en la Biblioteca Manuel Orozco y Berra, de la Dirección de Estudios Históricos del Instituto Nacional de Antropología e Historia, ambas en la Ciudad de México; y en la Biblioteca Histórica José María Lafragua, de la Benemérita Universidad Autónoma de la Ciudad de Puebla.

Todavía siguen sin compilarse como obra de conjunto y todavía desconocemos la totalidad de sus cartas pastorales que llegaron a publicarse mientras Lizana vivió en la Ciudad de México, en el periodo que va del año 1803 a 1810. Es imprescindible llevar a cabo esta previa tarea para conocer con exactitud el contenido y el alcance de su ideología, que siempre hay que considerar en la íntima relación de lo religioso con lo político. Pero una muestra, creemos que suficientemente representativa, de sus discursos, nos sirve ahora, después de su análisis, para aproximarnos a ella, a su ideología, e interpretarla, dentro de un contexto político problemático para la Corona española por fundamentarse en él la independencia de sus territorios indianos.

\section{Francisco Xavier de Lizana y Beaumont en el elogio fúnebre de José María de Alcalá y Orozco}

La Diócesis de México se erigió en 1530 y fue elevada a Arquidiócesis en 1546. Tiene su sede en la Ciudad de México y está a cargo del arzobispo de México. Desde el siglo XVI hasta finales del XVIII, llegó a contar con ocho diócesis sufragáneas. Los candidatos a arzobispo debían cumplir ciertas características como las de poseer un origen peninsular, una alta formación académica y una inquebrantable lealtad a la Corona.

Francisco Xavier de Lizana y Beaumont, natural de la ciudad de Arnedo, en la actual Comunidad Autónoma de La Rioja (España), nació el 13 de diciembre 
de $1749^{5}$ El elogio fúnebre de José María de Alcalá y Orozco (1813) sigue siendo la principal fuente por la que conocemos puntual información biográfica del arzobispo, y de ella nos servimos en este apartado. Obtuvo el título de doctor en Derecho Civil y Canónico por la Universidad de Zaragoza en 1771, a los 21 años. Al año siguiente se desempeñó como catedrático de concilios, promotor fiscal y vicario foráneo del ordinario en Alcalá de Henares. Hizo oposición a las canonjías de oficio de Sigüenza, Zamora y Toledo. Dos veces desempeñó el empleo de provisor, vicario general y gobernador del Obispado de Zamora durante dos vacantes de la silla episcopal. Se consagró como obispo auxiliar de Toledo el 21 de febrero de 1795, y de esta ciudad y de Madrid son conocidas sus prédicas públicas con "inmensos concursos de gentes".

El 2 de diciembre de 1801 entró como obispo en Teruel y se desempeñó como tal hasta el 28 de julio de 1802. Durante estos siete meses fueron frecuentes sus cartas pastorales y edictos para el buen gobierno de la diócesis. Con misiones para el pueblo y ejercicios para el clero predicaba, como lo hizo en México, en cumplimiento de lo ordenado a los obispos por el Concilio de Trento, los domingos. Tres veces, al parecer por quebrantos de salud, renunció a la propuesta de Carlos IV de ser arzobispo de México y, por fin, el 9 de octubre de 1802, el "segundo apóstol Xavier", como el rey lo llamaba, partió para Nueva España desde el puerto de Cádiz en el navío Miño. El 6 de diciembre llega al puerto de Veracruz y con un itinerario marcado por varias celebraciones en los curatos por donde debía pasar, llega a la Ciudad de México el 11 de enero de 1803 y toma posesión del cargo de arzobispo, como dijimos, el 29 del mismo mes.

Desde el comienzo se impone una férrea disciplina y transforma el palacio arzobispal en un, como dice el Elogio, "pobre y humilde monasterio". Al ambiente frívolo, de vanas diversiones, propio de la disipación palacial, le suceden el recogimiento, la modestia, el silencio, el decoro y la compostura. Fija horarios de despacho y visitas de oficio y pasa seis horas diarias dedicado a la oración y el estudio. Todos los días, a toque de campana, congregaba a su personal para rezar el rosario, ejercitarlo en la oración mental, en la lección espiritual y en otras prácticas de devoción que repasaban la doctrina cristiana.

5 Se le puso por nombre Francisco Xavier María, "hixo lexítimo de Don Joseph Bernardo Lizana, natural de Alcalá y de Doña Bernarda Beaumont y Robres; abuelos paternos Don Joseph Lizana natural de la villa de Robres y Doña María de Roxas, natural de Alcalá de Henares; maternos Don Xavier Beaumont, y Doña Inés de Robres naturales y vecinos de esta ciudad" (Libro de Bautizados de la Parroquia de Santo Tomás, año de 1749, Archivo Parroquial de Arnedo (La Rioja, España). 
De los rigores de su penitencia dan cuenta los instrumentos que se hallaron en sus gavetas: "rotas y despedazadas las crueles disciplinas, torcidos o embotados los garfios de los cilicios, y cansado o consumido el acero, de atormentar un cuerpo tan enfermo y delicado”. Según los testimonios de familiares de Lizana, que recoge Alcalá y Orozco, además de su ayuno ordinario y disciplina de cilicio, en Zamora tenía un féretro oculto a la familia en el que dormía los días de Semana Santa y en el que guardaba instrumentos para mortificar su cuerpo con penitencias.

Extenuado y pálido, débil y vacilante, modesto y mortificado en sus sentidos, con una imagen ejemplar de austeridad y penitencia, padeciendo enfermedades durante un largo tiempo, asuntos suyos fueron los propios de su cargo: las fundaciones de pueblos, como la del pueblo de indios de la Concepción de Arnedo, las divisiones de curatos, reparos de iglesias, dotaciones de sacerdotes para las parroquias, conferencias morales para la instrucción del clero, reformas en asuntos de liturgia, auxilio de pobres, confección de reglamentos para los tribunales eclesiásticos o la emisión continua y constante de cartas pastorales, cordilleras, edictos y sermones, que predicaba en las iglesias, hospitales, cárceles o cuarteles ${ }^{6}$.

En las críticas circunstancias prerrevolucionarias en las que se hallaba Nueva España, se le nombró virrey el 19 de julio de 1809 y estuvo en el cargo hasta el ocho de mayo de 1810. Murió el 6 de marzo de 1811 y sus albaceas se encargaron de hacer de su cuerpo reliquias que, en recipientes de plomo introducidos en cajas de madera forradas de terciopelo morado, distribuían partes de su corazón y de sus entrañas. Por voluntad del prelado se repartieron entre la capilla franciscana de la Real Congregación, conocida con el nombre de "Los Riojanos"; el convento de Jesús, Santa Teresa la Antigua, la Concepción y la Colegiata de Guadalupe ${ }^{7}$.

6 En los ocho años que gobernó, De Alcalá y Orozco nos dice que imprimió veinticinco cartas pastorales y que a su muerte se encontraron entre sus papeles "más de tres mil sermones". La información sobre los sermones puede ser exagerada, pero quiere mostrar aquí que realmente su actividad como lector y escritor de sermones y otros géneros de oratoria sagrada fue fecunda. J. M. de Alcalá y Orozco, , Virrey Elogio fúnebre del Excelentísimo e Ilustrísimo Señor Don Francisco Xavier de Lizana y Beaumont, Prelado, Gran Cruz del Orden de Carlos III y Arzobispo de México (México: en la Imprenta de Doña María Fernández de Jáuregui, 1813).

7 B. Bravo Rubio y M. A. Pérez Iturbe, "Una iglesia en busca de su independencia: el clero secular del Arzobispado de México, 1803-1822” (Tesis de Licenciado en Historia, Universidad Nacional Autónoma de México, 2001), 17. 
La formación doctrinal, jurídica e ilustrada de Lizana y Beaumont es fundamental para comprender el contenido de sus cartas pastorales, edictos y sermones, o sea, su papel como predicador en los púlpitos. Muestran las ideas y directrices de su gobierno y contextualizan la función de la Iglesia en la sociedad novohispana. Desde el último cuarto del siglo XVIII, la lealtad de los arzobispos a la Corona española se manifestó por medio de un patriotismo derivado de la idea de "nación española" sustentada con los valores de la tríada Dios, Patria y Rey.

En la Edad Media, el protagonismo en las iglesias se concentró más en el altar que en el púlpito, pero la predicación ya estaba considerada como un deber sacerdotal y se practicaba tanto en las calles y plazas como en las iglesias de las ciudades. El estilo de la predicación se adaptaba a la índole del público (urbano o rural, clerical o laico) y las posibilidades del medio oral eran así explotadas por los maestros de lo que en el siglo XVI se llamó "retórica eclesiástica”. Después de la Reforma, la predicación de "sermones dominicales" y "sermones festivos" se fue convirtiendo en una parte esencial de la formación religiosa y los gobiernos supieron conceder un valor a los púlpitos como medios de comunicación de masas, desde donde se podía transmitir información que estimulara la obediencia en relación con los intereses de la Iglesia y los estados. La reina Isabel I hablaba de la necesidad de "afinar los púlpitos" y Carlos I declaró que "en tiempos de paz, el púlpito gobierna más a la gente que la espada"8.

Entre fines del siglo XVIII y comienzos del XIX, una época de decisivas transformaciones políticas y sociales en la América hispana, las cartas pastorales y los sermones fueron medio de comunicación que todavía mantenía vigencia por su eficacia de alcance masivo. En la Nueva España fueron innumerables los discursos que pudieron imprimirse, y todavía más los predicados; de ahí que su mensaje religioso, ideológico, moral, educativo, político, los haya dotado de un valor histórico cuyos testimonios ofrecen modos de pensar, de imaginar, de decir.

El sermón es un género de la oratoria sagrada cuya lectura se realiza en el contexto de una celebración litúrgica; por ello mantiene unas características de formalidad y de solemnidad que lo diferencian de otras formas de predicación cristiana como la homilía y la catequesis. Su forma textual presenta unos valores literarios procedentes de la retórica clásica; un arte sujeto a un conjunto de normas dirigidas hacia la persuasión. Podía crearse a iniciativa personal, pero la

8 A. Brigs y P. Burke, De Gutenberg a Internet. Una historia social de los medios de comunicación (Madrid: Taurus/Santillana, 2001), 40-41. 
mayoría eran encargados por particulares, cofradías, conventos, universidades y otras instituciones civiles y eclesiásticas. Los medios económicos para su impresión solían ser solventados por quienes los encargaban, pero estaba sujeta a los censores del Tribunal del Santo Oficio.

Los tratados de retórica y "artes" de sermones para predicadores, basados en la retórica clásica, hacían que los textos adquiriesen uniformidad y giraban alrededor de tres ejes: el predicador (sus virtudes), la materia del sermón (generalmente, como base, las Sagradas Escrituras) y los modos de decir (las técnicas o mecanismos retóricos). Las pastorales y edictos, aunque mantienen características de escritura y dicción pública similares a las de los sermones, son menos ricas en metáforas, imágenes o metonimias que ellos. En materia moral se exige un estilo apropiado que no trata de demostrar una tesis o de argumentar, sino de prescribir y de exhortar. Las pastorales reproducen las exigencias del arzobispo a sus súbditos eclesiásticos sobre su ministerio y vida conventual y las exigencias a los seglares en cuanto a su vida cristiana. Las proclamas, en cambio, son consejos o súplicas propias de la autoridad real que, en este caso, Lizana representó como virrey. En cualquier caso, lo moral, lo doctrinal o lo político en conexión con la materia como tal del discurso sonlo que nos interesa analizar ahora, no los matices formales que distinguen cada uno de los distintos géneros de la prédica religiosa.

\section{El discurso ideológico del arzobispo-virrey}

La oratoria sagrada, representada en distintas tipologías documentales como el sermón, la carta pastoral, la instrucción, la exhortación, el edicto o la proclama, fue un medio de difusión de patrones ideológicos y culturales que la Corona española, al lado de la Iglesia, y como poder establecido en las Indias, utilizó en sus funciones evangelizadores y en el adoctrinamiento de la sociedad.

El Concilio de Trento (1545-1563) reforzó las formas de evangelización y, entre ellas, la predicación debía expresar y hacer sentir de manera breve y sencilla la oposición entre los vicios del hombre, que debían rechazarse, y las virtudes, que debían practicarse. La oralidad, en tanto reproduce el contenido fonético de lo escrito (manuscrito o impreso), difunde determinadas estructuras y formas literarias que se acentúan ante la escucha del público y van más allá del mensaje religioso, dando lugar a representaciones íntimas y morales que se forman en la conciencia del receptor.

Mover los "afectos" desde una determinada estrategia argumentativa es el objetivo principal del discurso, para el cual el orador utiliza una carga pasional 
y cierto grado de intensidad que ayuden a persuadir. Los afectos, pensados como el conjunto de respuestas psicológicas, emocionales y cognitivas hacia el entorno físico y sociocultural. Se trataría de considerar los afectos ylas emociones como "construcciones discursivas", relacionándolos con conceptos como la "autopresentación" o la "argumentación”; los afectos, de ahí el paso a las representaciones, como "práctica social", más que como una "expresión de tipo mental", que contribuyen a la "cohesión del grupo" o a "crear colectivos de identificación”"9.

La práctica del sermón o la carta pastoral es una manifestación cultural siempre dirigida a conseguir unos fines concretos y solo desde ellos se comienza a escribir. Utilizando material propio y ajeno, la construcción literaria resultante no debe olvidar el sentido ni el alcance de la palabra oral, pues son escritos encaminados, en su sentido original, a su proclamación ante auditorios heterogéneos. El discurso, tal como lo expuso el orador y tal como fue escuchado en su contexto escénico, guarda una distancia considerable con el texto escrito y su lectura silenciosa, no solo de tiempo y espacio. La oralidad adquiere un significado distinto por la modulación e impostación de la voz que se coordina con los ademanes, la gesticulación, la mirada, la presencia en movimiento del cuerpo entero del orador. La prédica es, por tanto, una puesta en escena dirigida, al mismo tiempo, al oído y a la vista.

La posible impresión posterior de los textos conllevaría luego otro tipo de difusión y circulación, pero oralidad y escritura siempre estarían retroalimentándose en la construcción primigenia del discurso y en su práctica divulgativa posterior, tanto oral como impresa, pues es un discurso que, además de ser enfocado a un diverso público de alfabetos y analfabetos, también es captado por otros predicadores a quienes les sirve como inspiración personal para su recreación o, simplemente, para su propia copia. Digamos que el alcance de la oratoria sagrada encuentra una doble circulación, la oral y la escrita, y esta última, indudablemente, está dirigida a un público alfabeto, más concreto y selecto, compuesto por los propios predicadores y lectores fieles y devotos.

Los sermones o cartas pastorales, sin embargo, también podían escribirse para pasar directamente a la imprenta, sin previa prédica. Antes de la llegada a México de Lizana, en España ya se había ejercitado ampliamente en la práctica oral y era consciente de las diferencias entre la escucha y la lectura, ya que, en esta última, falta la "energía de la voz" y la predicación pierde sus naturales

9 M. Jiménez Rodríguez, "La emoción como estrategia argumentativa en el mitin español", Discurso y Sociedad 11, n.. 4 (2017):, 623, 624. 
facultades. La predicación oral puede volver sobre lo ya dicho, insistir mediante repeticiones en lo esencial del discurso y no detenerse en el estilo literario que le da forma, transmitir mensajes en compañía del "rebaño" y no en la soledad del lector:

Amados mios bien conozco que no es tan poderosa para movernos la pluma como la voz viva; y aunque es cierto que en ausencia puede el Doctor enseñar, es innegable que faltando la energía de la voz viva, pierde la predicación gran parte de su eficacia. Asi lo sentía el grande Pablo quando escribiendo á los Gálatas les decía: deseo verme en vuestra compañía, mudar el estilo por la voz, y que hable la lengua, lo que no puede explicar la pluma ${ }^{10}$.

Pero el texto escrito suple, por otro lado, la ausencia del orador y puede trasladarse en la distancia a distintos receptores y en distintas ubicaciones. No pudiendo visitar personalmente todo su rebaño, "ni anunciar la palabra de Dios a todos los Pueblos" de su "vasta viña", Lizana desea "dar algún alivio al dolor y pena" que por ello padece, enviando sus cartas pastorales escritas a las distintas diócesis que dirige.

El crecimiento de las ciudades como centros del poder político y las órdenes mendicantes impulsaron la predicación en la ciudad de México. Si en el siglo XVII novohispano, frente a la predicación dirigida a la instrucción de los fieles en sus modalidades de homilía, catequesis o plática, el sermón representaba una prédica elitista, a fines del siglo XVIII, cuando todavía predominaba una cultura oral, el aumento de las imprentas y los auditorios hicieron que el sermón pudiera contar con un mayor público lector y oidor.

Al lado de las novenas y las hojas de devoción, la impresión de sermones, aunque no se publicaban todos los que se pronunciaban en el púlpito, responde al prestigio y la competencia que existía entre los predicadores por publicar. Tener sermones impresos, o incluso sermonarios, aumentaba el prestigio de los mismos Este, el lucimiento o prestigio personal, era un motivo más que hay que añadir a los motivos más frecuentes por los que los predicadores justificaban la impresión de sus sermones o pastorales: el obedecimiento a

${ }^{10}$ Francisco Xavier de Lizana y Beaumont, Carta pastoral, que el Ilustrísimo Señor Doctor Francisco Xavier de Lizana y Beaumont Arzobispo de México, del Consejo de Su Magestad, etc., dirige a los fieles de su Arzobispado sobre Grandeza de nuestra Santa Religión, en lo que enseña, manda creer y practicar (México: Imprenta Madrileña de la Calle de Santo Domingo, y Esquina de Tacuba, año de 1803) 3,4. 
los mandatos superiores, la instrucción de los predicadores novatos y de los fieles, la reparación del daño que hacían los libros profanos, la protección de sus textos de los "memorillas", que copiaban las proclamas de los púlpitos para presentarlas como propias, y la defensa de la lengua castellana.

Generalmente, cuando la prédica estaba destinada exclusivamente al púlpito, los oradores podían valerse solo de notas y a partir de ellas desarrollar su discurso; otros lo escribían en forma de borrador y, si lo presentaban a la imprenta, se hacía necesario reescribirlo, colocando las citas, cambiando la estructura, ampliando algunas de sus partes o mejorando estilo y argumentaciones. La impresión aumentó la extensión de los discursos y exigió un trabajo más elaborado de lo que la exposición oral pedía ${ }^{11}$.

Las primeras imprentas estaban al servicio de la Iglesia, que comenzó a publicar piezas oratorias, especialmente sermones. En comparación con otros géneros, ya desde el siglo XVII los sermones impresos fueron aumentando significativamente, aunque esto no condujo necesariamente al incremento de la erudición ni al intercambio cultural. La impresión transformó la práctica misma del discurso y los religiosos fueron valorando cada vez más la impresión como práctica superior a la dicción oral, debido a la permanencia y la vastedad del auditorio que permite el texto impreso frente a lo efímero y lo disperso del mensaje oral. La oralidad se tornará residual, huella, y poco a poco seguirá las reglas de lo escrito; reglas que serán las de la futura modernidad en la que la escritura supone ser, en la veracidad y la oficialidad de los actos, el sostén de la oralidad ${ }^{12}$.

Carlos Herrejón hace una clasificación de los sermones novohispanos ubicándolos en contextos culturales de época: el sermón barroco, el de transición, el neoclásico y el de una nueva transición. El periodo de transición entre barroco y neoclásico comenzaría alrededor de 1760 e iría hasta la década de los setenta. Los contemporáneos hablaban de predicar "a la moderna" o "a la francesa”, con rasgos característicos como la vuelta a los modelos clásicos (a los predicadores de la patrística, a los del Siglo de Oro español y a los oradores franceses del siglo de Luis XIV), una mayor racionalidad, claridad y regulación

${ }^{11}$ F. Herrero Salgado, La oratoria sagrada española de los siglos XVI y XVII (Madrid: Fundación Universitaria Española, 1993), 125-130.

12 P. Chinchilla Pawling, De la “compositio loci” a la república de las letras. Predicación jesuita en el siglo XVII novohispano (México D. F.: Universidad Iberoamericana, 2004), 15-50, 247-305. 
en el contexto de una "renovación cristiana del siglo XVIII" o de una, como se ha denominado, "ilustración católica".

El periodo neoclásico abarcaría desde el último tercio del siglo XVIII hasta 1810. Es aquí cuando la prosa de Lizana muestra fluidez, y esta fue una de las preocupaciones básicas en los reformadores de la predicación cristiana; algo que se ligó a la moderación de las citas en latín, mucho más abundantes en el sermón barroco. La fluidez posibilita desarrollar otro tipo de recursos como las interrogaciones, las interpelaciones, las enumeraciones o las gradaciones, ampliamente utilizadas por el arzobispo, que permiten levantar el tono del discurso y vigorizarlo. La fluidez hace posible también una prosa cadenciosa que se adapta con mayor flexibilidad a las modulaciones de la voz y al agrado del oído ${ }^{13}$.

El 30 de enero de 1803, al día siguiente de su nombramiento, el arzobispo, en cumplimiento de la "servidumbre honorífica del cargo pastoral" que recayó en él por "gracia de nuestro Católico Monarca", emite su primer edicto. Remontándose al origen de las pastorales con la prédica de san Pablo, se dirige al clero mexicano con el deseo de hablar "boca a boca, según la expresión del Apóstol" y con "ingenuidad, con candor y con amor de Pastor y Padre". Su propósito inicial es renovar el sacerdocio para "renovar el espíritu de nuestro ministerio" y corregir "la depravación del siglo con la pureza e integridad de vuestra doctrina y costumbres". Para ello presenta un programa basado fundamentalmente en ejercicios espirituales: "un rato de recolección en la Iglesia [...], a las diez por la mañana, y a las quatro por la tarde, a que dará fin la plática, este será el método que observaremos, permaneciendo el resto del día cada uno de vosotros con la abstracción y retiro correspondiente, o en la misma casa particular en que vive, o en la Comunidad que elija"14.

La preocupación de Lizana por la preparación espiritual de sus diocesanos va a ser constante. Tomando el ejemplo de los ejercicios que se practicaban en la llamada "Puerta del cielo", el oratorio de san Felipe Neri, y dadas las diversas ocupaciones de los sacerdotes, que les impedían "retirarse con total abstracción”, cree conveniente practicar unos ejercicios abiertos al público y no en el retiro sacerdotal. El fin de los mismos es el arreglo de las conductas y la reforma de las costumbres que, desde la fe, con una "total conformidad con la divina voluntad", conduzca a la "salvación eterna”. El retiro espiritual,

${ }^{13}$ C. Herrejón Peredo, Del sermón al discurso cívico: México, 1760-1834 (México D. F.: El Colegio de Michoacán/ El Colegio de México, 2003), 20-21.

${ }^{14}$ Gaceta de México, 11 de febrero de 1803, 238. 
apartándose temporalmente de los negocios terrenales para buscar a Dios, es un camino seguro para "volver a la gracia”. Según las reglas de los santos, los medios para conseguir la salvación son la lección espiritual, la meditación y el examen de conciencia, usando de ellos con prudencia y atención ${ }^{15}$.

Una carta pastoral de 1807 señala las obligaciones del sacerdote de mediar con Dios en favor del pueblo, predicando con doctrina y ejemplo para "salvar las almas, destruir el pecado y plantar las virtudes”. Recuerda las obligaciones establecidas en el Concilio de Trento para que los obispos exhorten a sus clérigos para que con "su porte, palabras y ciencia” edifiquen al pueblo. Desde la diferencia que entre "legos" y "clérigos" señala, incluye en sus obligaciones a todos los "eclesiásticos y ministros" de Dios:

No solo los Obispos, los Presbiteros y Diaconos deben con el mayor cuidado procurar proceder con su sabiduría, palabras y porte a todo el pueblo que preside; sino también el grado inferior exorcistas, lectores, ostiarios, acólitos, y todos los que sirven de qualquiera suerte en la casa del Señor, porque destruye en gran manera la Iglesia de Cristo que los legos sean mejores que los clérigos ${ }^{16}$.

La práctica de ejercicios espirituales en la que insistió tanto el arzobispo quiere fortalecer la fe para edificar al pueblo desde el ejemplo educativo de los sacerdotes. La fe parece debilitarse en comparación con las cartas de san Pablo, pues no aparece ya como el inicio de la justificación, de la apertura ante Dios, sino como una virtud entre otras. La fe no indica ya una actitud interior de entrega, sino que parece haber evolucionado a una adhesión intelectual o doctrinal:

No ha sido otro el designio que hasta ahora hemos tenido en las Cartas Pastorales que os hemos dirigido, que cumplir las estrechas obligaciones de nuestro sagrado ministerio, conducir vuestras almas por las sendas rectas de la justicia, y sostenerlas con la Doctrina pura ${ }^{17}$.

${ }^{15}$ Lizana y Beaumont, Carta pastoral [dirigida] a sus diocesanos con el fin de exhortarlos y prepararlos para unos Exercicios espirituales públicos (México: por D. Mariano de Zúñiga y Ontiveros, calle del Espíritu Santo, año de 1804), 2, 4, 9, 13.

${ }^{16}$ Lizana y Beaumont, Carta pastoral [dirigida] a su clero sobre la santidad del estado Sacerdotaly obligaciones inseparables de él (México: Oficina de la calle de Santo Domingo, 1807), 6, 40.

${ }^{17}$ Lizana y Beaumont, Carta Pastoral en la que [...] Instruye a los fieles sobre el juego y los desarreglos que en él se hallan (México: en la Imprenta de D. Mariano de Zúñiga y Ontiveros, año de 1804), 1. 
Una "Doctrina inconcusa" que da la oficialidad de la Iglesia,"declarada por los Sumos Pontífices, establecida en los Cánones y Concilios, enseñada por los Santos Padres y Doctores, y el fundamento sobre que los Patriarcas fundaron las Religiones que ilustran la Iglesia"18.

Cris Grass van der Laan ha estudiado la moral cristiana en las pastorales de san Pablo y, en general, podemos decir que los discursos de Lizana, quien tantas veces nombra y cita al apóstol en el cumplimiento de sus funciones, también reflejan un "cristianismo burgués" emparentado con el mensaje de san Pablo que, sin ser un cristianismo estático, habla de la gracia que "educa a vivir con prudencia, justicia y piedad en este mundo" ${ }^{19}$. Lo cual señala algunas características de este tipo de cristianismo:

1. Un cristianismo que, sin dejar de dirigirse a los pobres, puede desarrollarse en círculos más elevados. Un indicio de ello sería el cambio de actitud de la Iglesia en cuanto al bienestar material que, de ser distante, pasa a ser aceptado.

2. Una adaptación a la cultura por medio de la educación, ajena al carácter irracional y a la fe del Evangelio. Las pastorales de Lizana apelan más a la racionalidad del Evangelio que a su poder relacionado con lo espiritual. Se buscaría en realidad un acercamiento y acomodación bajo "el ideal de ciudadanía cristiana”.

3. Hay un conservatismo en el discurso del arzobispo, que buscareglas en el mundo actual para ordenar temporalmente la vida y las encuentra en el material tradicional de la ética cristiana. Factores como la buena conciencia, las buenas obras, la fe, la caridad, la piedad y la dignidad deben regular la vida cristiana dirigida a un "ética doméstica", es decir, el ejercicio de virtudes adaptadas al estado de vida individual.

La fe como virtud aparece con frecuencia en los discursos de Lizana en conexión con otras virtudes como la obediencia, la benignidad, la confianza, el

${ }^{18}$ Lizana y Beaumont, Exhortación [dirigida] a los Conventos de Religiosas de su Filiación. Sobre algunas preocupaciones opuestas a la puntual observancia de sus deberes (México: en la Oficina de Doña María Fernández de Jáuregui. Calle de Santo Domingo, año de 1808), 9.

${ }^{19}$ C. G. Laan, "La moral cristiana en las cartas pastorales de san Pablo" (Tesis Doctoral, Facultad de Teología, Universidad de Navarra (Pamplona), 1999), 25-90, https://adun.unav.edu/ bitstream/10171/11586/1/CDT_XXXVI_01.pdf 
buen ánimo, etc. Los inventarios de virtudes y vicios son una de las formas de exhortación de las epístolas del Nuevo Testamento. Son un modelo sintético de manifestar las exigencias de la vida cristiana y de exhortar a la conversión y la perfección. La idea de virtud supone la posibilidad de crecimiento espiritual y Lizana pide la fe con un sentido dinámico, con un sentido objetivo:

Yo el consejo del Apostol [sic], inste y clame sin cesar en mis pastorales, edictos y cartas familiares á mis amados Sacerdotes para que velen sobre vosotros a fin de que no os desviéis del camino del Cielo, y si habéis errado os reduzcan á las sendas de la salud y vida eterna ${ }^{20}$.

El conocimiento de Dios es o produce la piedad. El hombre piadoso es el hombre justo. El carácter espiritual de la piedad no solo contrasta con el culto al cuerpo, sino también con el afán de riquezas. La condición para que la piedad se cumpla es la autosuficiencia; contentarse con una vida sobria en desarrollo de una disciplina personal. La piedad puede ser relacionada con las buenas obras, tan destacadas en las Pastorales de san Pablo. Unas obras que van más allá del sentido terapéutico de la existencia cristiana. La actuación del cristiano depende de la gracia divina. Las obras se hacen buenas por la gracia y por ello no se oponen a la justificación por la fe, sino que son su producto. Las buenas obras tienen también una función escatológica, son fuente de mérito. A los ricos se les ordena que no sean arrogantes y se les advierte contra los peligros de los bienes materiales o la riqueza. La exigencia de las buenas obras para las mujeres supone un plano de igualdad en materia religiosa entre el hombre y la mujer. La demanda de modestia y sobriedad en el arreglo femenino evita, por otro lado, que las diferencias sociales, tan acentuadas en la sociedad colonial, puedan influir en las celebraciones cristianas.

En esa instrucción constante por medio de ejercicios espirituales a sus "súbditos" del clero, a los que les dice, "vengo a buscar [...] no vuestras riquezas, sino vuestras almas"21, a través del "propio conocimiento, el amor de la virtud, y la preparación a una buena muerte”, ofrece una extensa relación de virtudes que hay que observar para el buen obrar: "la justicia, y con ella la Religión, piedad, obediencia, veracidad, agradecimiento, benignidad, atención y afabilidad con otras muchas virtudes. Es fuerte el hombre iluminado por la fe y su alma "desea enriquecerse en méritos para la vida eterna”, posee así "la magnanimidad,

${ }^{20}$ Lizana y Beaumont, Carta pastoral [...] sobre Grandeza de nuestra Santa Religión, 5.

${ }^{21}$ Lizana y Beaumont, Carta pastoral [...] sobre Grandeza de nuestra Santa Religión, 4. 
paciencia, longanimidad, confianza, buen ánimo, perseverancia y otras semejantes: es templado, casto, abstinente, manso, piadoso, humilde, modesto y severo para sí mismo". Y después del largo listado de virtudes, es diciente su conclusión: " $¡ O$ qué Ciudadanos tan útiles á la sociedad, tan amables á Dios y á los hombres, los que se gobiernan por estos principios!”22.

En el "sermón moral" que predicó la noche del 31 de diciembre de 1805 en la iglesia metropolitana, se dirige al "Pueblo Mexicano" para que, desde los favores que concede la "Divina Piedad", el próximo año se eviten "los males y penas". Hace un listado de pecados ("las torpezas de los jóvenes; los amancebamientos de los casados, la insaciable codicia del comercio, el orgullo, sobervia y luxo en los ricos, las embriagueces, rapiñas, hurtos y vida criminal, ociosa, é inutíl de los pobres, la falta de pudor y modestia en las doncellas; el libertinaje y desahogo en las casadas") y acaba hablando del horror que produce la "desnudez atrevida y diabólica de las mujeres" y el "pésimo vicio del juego" 23 .

Las pastorales de Lizana contienen abundantes normas morales prácticas y podemos preguntarnos si estas surgen del sentido moral del Evangelio o son más bien una adaptación a la ética contemporánea. El imperativo ético de las pastorales se explicaría por la ocasión de poder ofrecer directrices a la comunidad desde determinadas circunstancias. El lenguaje literario de las pastorales, como el lenguaje metafórico del Evangelio, y las frecuentes listas de virtudes y vicios hacen pensar en una continua adaptación del cristianismo al modo de vivir y a la mentalidad de las sucesivas épocas. Los listados de virtudes y vicios son un recurso con fines didácticos que de manera general y sencilla, mediante oposiciones claras, resalta los conceptos y ha dado lugar a interpretar la moral de las pastorales de san Pablo como una "moral burguesa" 24 .

Había una trayectoria marcada por el IV Concilio mexicano de 1771, a partir del cual obispos y arzobispos que ejercieron antes de Lizana reforzaron la necesidad de colaborar conjuntamente con el Estado en la consecución de metas político-religiosas con algunas medidas prácticas: el alejamiento del clero

${ }^{22}$ Lizana y Beaumont, Carta Pastoral en la que [...] Instruye a sus súbditos sobre los desengaños y frutos que han debido sacar de los Exercicios espirituales que acaban de practicar (México: por D. Mariano de Zúñiga y Ontiveros, calle del Espíritu Santo, año de 1804), 2, 7, 8.

${ }^{23}$ Lizana y Beaumont, Sermón moral que en la solemne acción de gracias, que se hace anualmente en el Sagrario de esta Santa Iglesia Metropolitana de México por los beneficios recibidos de la Divina Piedad, predicóla noche del día 31 de Diciembre de 1805 el Ilustrísimo Señor Don Francisco Xavier de Lizana y Beaumont, Arzobispo de dicha Santa Iglesia (México: en la oficina de Doña María Fernández Jáuregui, calle de Santo Domingo, año de 1806), VI-VII.

${ }^{24}$ Sobre el concepto de "moral burguesa”, ver Laan, "La moral cristiana”, 45. 
de las corrientes teológicas para acercarse a la población; la recta educación cristiana, que disminuiría la ociosidad y aumentaría la producción y circulación de bienes, mejorando a la vez la hacienda pública del Estado; el cumplimiento de las funciones sacerdotales; una religiosidad de amor hacia el indio, y la exigencia, mayor después de la Revolución francesa, de compatibilizar las enseñanzas del clero con las necesidades del Estado.

La consecución de "ciudadanos útiles" a la sociedad por medio de "los oráculos de la Religión”, de su creencia en ellos y de su observación y cumplimiento hay que ponerla en relación con la política religiosa que inicia Carlos III con unos objetivos de mantener el control del Estado sobre la Iglesia, mejorar la calidad del clero, asegurar los servicios que de él se recibían y depurar las manifestaciones heterodoxas de la religiosidad ${ }^{25}$. Dentro del programa de reformas eclesiásticas, en 1787, Carlos IV y el conde de Floridablanca recomendaban que se redujera la extensión de los obispados para facilitar su administración con el fomento de la ilustración del clero, instruyéndole en materias como las ciencias, la economía política y el derecho civil con el fin de educar al pueblo. Hay un desplazamiento del interés religioso por el político-social.

Concebida en el marco de la ilustración católica, Lizana fundó en 1804 la Congregación de Eclesiásticos Oblatos con el fin de atender a presos, soldados, enfermos, matrimonios desavenidos y niños de escuelas. Era una asociación de clérigos que, sin dejar su adscripción diocesana, buscaba una mayor entrega al ministerio sacerdotal y una mayor espiritualidad. La Congregación hacía parte de un proyecto del arzobispo en su misión pastoral y se centraba en una constante predicación y en obras de misericordia. Medidas estrictas, ejercicios espirituales, sesiones con los párrocos, reglamentación de tribunales eclesiásticos, fueron algunas medidas de la Congregación que se llevaron a cabo dentro de una reforma de división de parroquias. Se fomentaron los vínculos de solidaridad de los sacerdotes, pero la Congregación se debilitó con la guerra de la Independencia ${ }^{26}$.

La religiosidad, desde sus prácticas de fe y actos sociales del culto, se polarizó con el régimen borbónico español, asociado con acelerados cambios organizativos que propulsaron mejoras productivas, comerciales, militares y educativas para lograr mayor competitividad internacional. Una corriente de

${ }^{25}$ Cf. Domínguez Ortiz, Carlos III, 240-275 y Rodríguez Casado, "Iglesia y Estado", 5, 57.

${ }^{26}$ F. Pérez Memen, El episcopado y la Independencia de México (1810-1836) (México D. F.: Editorial JUS, 1977), 219. 
la Iglesia aceptó y colaboró con los nuevos objetivos del Estado, y la otra fue recelosa por sus tradicionales privilegios. Una nueva religiosidad comenzaba a configurarse, asociada a un "nuevo concepto económico-social de la vida" para el cual el Estado impuso a la Iglesia una rigurosa disciplina, con el acotamiento de los bienes del clero, el fin de la inmunidad fiscal y su mayor participación en obras comunes del Estado y la Iglesia. Se pretendió que una práctica religiosa, de "íntima convicción y alto valor ético", se abriera a los cambios propuestos por el Estado y fuera a la vez sostén de la salvación y de la formación ciudadana más ejemplar. La educación, el trabajo y el ahorro serían virtudes de una conducta orientada a una "vida bien regida" y a la "felicidad como bienestar del mundo”. La ociosidad se concibió enemiga del trabajo y la previsión se volvió una obligación moral atendida por la prudencia, la constancia y una conducta disciplinada y laboriosa ${ }^{27}$.

En la carta pastoral de Lizana, dedicada a la "Grandeza de nuestra Santa Religión”28, no solo ruega a las máximas autoridades (virreyes, gobernadores y jueces), que están obligadas "a mirar por el aumento de la Religión y de la Patria", sino también a quienes más directamente estaban encargados de educar a la ciudadanía, a los "Maestros de letras", para que trabajen cuanto puedan en "civilizar las gentes y aficionarlas a las cosas sagradas". En esta súplica incluye a los "tantos ciegos y miserables indios engañados por el demonio, a quienes aún no ha cabido la dicha [...] de poseer el precioso don de la fe". Comprueba que todavía hay una falta de instrucción en los pueblos de su Arquidiócesis, no solo en cuestiones relacionadas con la "policía y docilidad", también en la "Doctrina Cristiana", y habla de la "ínfima plebe" de la "populosa Capital de México" que se encuentra por sus barrios. “Qué son estos?”, pregunta Lizana con el recurso pedagógico de la interrogación. Desde unos presupuestos utilitaristas responde con una sobrecarga semántica de cualidades negativas amplificadas, motivada por su finalidad, la del verdadero rechazo a ellas: "Un horizonte, de donde parece se retira aun la luz de la razón: son la habitación del ínfimo pueblo: madriguera de vicios: teatro de la embriaguez más descarada. Son en fin, los

${ }^{27}$ B. F. Connaughton, "Transiciones en la cultura político/religiosa mexicana, siglo XVII. 1860: el aguijón de la economía política”, en Poder civil y catolicismo en México, siglos XVI al XIX, ed. F. J. Cervantes Bello, A. Tecuanhuey Sandoval y M. P. Martínez López-Cano (México D. F.: Benemérita Universidad Autónoma de Puebla-Instituto de Ciencias Sociales y Humanidades "Alfonso Vélez Pliego"-/Universidad Nacional Autónoma de México -Instituto de Investigaciones Históricas-, 2008), 450, 452. https://www.historicas.unam.mx/publicaciones/ publicadigital/libros/podercivil/pcivil020.pdf

${ }^{28}$ Lizana y Beaumont, Carta pastoral [...] sobre Grandeza de nuestra Santa Religión. 
que proveen las Cárceles de delinqüentes, y á la Ciudad de artesanos dolosos; porque desde la niñez les falto la instrucción, crianza, cultivo, temor a Dios, y aun el conocimiento". Educación y "temor a Dios", entendido este como la piedad, o sea, el temor reverencial y el estupor por las cosas elevadas y puras de lo divino. El propósito final, remarca luego, es que sus "ideas" ayuden "para instruir y civilizar los pueblos".

Una educación que no olvida la unificación lingüística. En la misma carta pastoral, más adelante, con el fin de "hacer mas cultas estas Naciones", propone que se "destierren de las Indias los diversos idiomas", y que todos los pueblos "fuesen de una sola lengua":

La Religión, el estado, y los mismos pueblos adelantarían más: los Párrocos y los Misioneros con menos trabajo fructificarían más: el comercio giraría menos arriesgado: crecería el número de los individuos de la verdadera sociedad: los que gastan el tiempo en estudiar tan varios idiomas, lo emplearían mejor en el estudio de ciencias útiles para instruir á los Pueblos, y confutar los errores y abusos del vulgo ignorante [...] Yo he leído una carta que escribió á Paulo tercero el Ilmo. Señor Don Fray Julian Garces, Obispo de la Puebla de los Ángeles, en que le decía: que los niños de los Indios son de mucha penetración, y sublimidad de ingenio con ventaja a los Españoles. Luego el no haberse desterrado yá de las Indias esa confusa Babel de lenguas es, porque los Maestros de los párvulos, y los padres de familia no trabajan, sobre este punto tan interesante á la Religión, al Estado, $\mathrm{y}$ al bien de las almas ${ }^{29}$.

La tendencia predominante entre doctrineros, religiosos y funcionarios fue la de formar pueblos con tribus y lenguas similares, pues, políticamente, las colectividades integradas por elementos heterogéneos resultaban muy difíciles de gobernar. Bajo consideraciones religiosas o sociales, o bajo un barniz humanista, las disposiciones reales sobre la enseñanza de la lengua castellana a menudo acompañan textos que hacían referencia al aspecto político de vivir en "policía y buenas costumbres" (Real Cédula del 7 de junio de 1550); "enseñarlas

${ }^{29}$ Lizana y Beaumont, Carta pastoral [...] sobre Grandeza de nuestra Santa Religión, 13, 23, 25. 
otras cosas necesarias a la vida política”30; "consigan otras utilidades en su gobierno y modo de vivir" 31 , etc.

En el mismo sentido en que se pronuncia Lizana, ya se había pronunciado el virrey de la Plata del Perú en carta dirigida a la Corona el 30 de noviembre de 1682:

No hay máxima más cierta, más útil ni más practicada en las conquistas de nuevos dominios que la de establecer en ellos las leyes, la lengua, y las costumbres de la nación dominante, y esto se consigue por los medios de introducirlos en sociedad política componiendo las poblaciones de uno y otro gentío, para que con la comunicación, el tiempo los haga a todos como de una misma ley, de unas mismas costumbres y seguridad ${ }^{32}$.

A partir de finales del siglo XVII la actitud de la metrópoli fue cambiando hacia tendencias secularizantes y, así, el deseo evangelizador de la enseñanza de la lengua castellana se fue reduciendo y sustituyendo por un interés político. Durante el siglo XVIII y, sobre todo, ya avanzado este, el Consejo de Indias promovió las tendencias unitarias acordes a las manifestaciones del sentimiento nacionalista que caracterizó la vida social y la organización política de los países europeos. En diversos campos fue un fenómeno generalizado en el siglo XVIII fortalecer la modernidad europea oponiéndola al salvajismo prehistórico del resto del mundo.

El concluyente interés político y cultural, característico del siglo de la Ilustración, se va a evidenciar en las ideas de un arzobispo que precedió a Lizana, Francisco Antonio Lorenzana; ideas que inspiraron la famosa Real Cédula del 16 de abril de 1770:

El hablarse un mismo Idioma en una Nación propia de su soberano, y único Monarca, engendra cierto amor, e inclinación de unas personas, a otras, una familiaridad, que no cabe entre los que no se entienden, y una sociedad, hermandad, civilidad, y policía, que conduce mucho para el

${ }^{30}$ Recopilación de leyes de los reynos de las Yndias mandadas imprimir y publicar por la magestad católica del rey D. Carlos III, Tomo I, Libro I, Tít. III, Ley XIX (Madrid: Julián de Paredes, 1681), fol. 13. http://www.bibliotecanacionaldigital.gob.cl/visor/BND:8940. (Replica instrucciones reales de 1612 y 1624$)$.

${ }^{31}$ Recopilación, Tomo I, Libro I, Tít. XIII, Ley V, fol. 56. http://www.bibliotecanacionaldigital. gob.cl/visor/BND:8940. (Replica instrucciones reales de 1634 y 1636).

32 Magnus Mörner, La Corona española y los foráneos en los pueblos de indios de América (Estocolmo: Almqvist y Wiksell, 1970), 185. 
gobierno espiritual, para el trato doméstico, para el comercio, y política, como también para ir olvidando los conquistados insensiblemente sus enemistades, sus divisiones, sus parcialidades, y su aversión a los que mandan $^{33}$.

La guerra de la independencia cambió los contenidos de la predicación, y las formalidades del discurso son desplazadas por intereses políticos, y se generó así el clima para el nacimiento del discurso cívico. A partir de 1808, los púlpitos se dedican a la defensa patriótica de la monarquía. La invasión napoleónica y la posición de José Bonaparte como rey de España y de las Indias se representaron como castigo, y el malestar aumentó con las acciones independentistas de Miguel Hidalgo y José María Morelos. Se mantiene el estilo neoclásico, pero la mesura del buen gusto cambia por la vehemencia de las pasiones. Los sermones antinsurgentes frecuentemente poseen forma neoclásica y un espíritu patético que los acerca al Romanticismo. Se evitan largas citas latinas para entender adecuadamente la prédica; las referencias bíblicas a personajes y episodios siguen siendo hilo conductor. La preocupación patriótica fue dando paso a la social y política e implicó al mismo tiempo mayor cohesión de la población novohispana. La fidelidad al rey y el odio a Napoleón y a los franceses se fomentó a través de los sermones; pero también, desde el trasfondo de la renovación del cristianismo, desde la ilustración católica y el jansenismo que procuraban la autenticidad de la fe y las exigencias evangélicas, los sermones podían conducir a una actitud pacifista frente a las agresiones bélicas del imperio napoleónico ${ }^{34}$.

${ }^{33}$ Fragmento de la pastoral del arzobispo de México, Lorenzana, del 6 de octubre de 1769 [H. Triana y Antorveza, Las lenguas indígenas en la historia social del Nuevo Reino de Granada (Bogotá: Instituto Caro y Cuervo, 1987), 503]. Influenciado por la carta que el arzobispo de México, Francisco Antonio Lorenzana, escribió el 25 de junio de 1769 al rey Carlos III, este emitió la Real Cédula del 16 de abril de 1770, encabezada por las ideas ilustradas que contenía dicha carta, "a fin de que se instruya a los Indios en los Dogmas de nuestra Religión en Castellano, y se les enseñe a leer y escribir en este idioma, que se debe extender y hacer único y universal en los mismos Dominios, por ser el propio de los Monarcas y Conquistadores, para facilitar la administración y pasto espiritual a los naturales y [...] para que de una vez se llegue a conseguir el que se extingan los diferentes idiomas de que se usa en los mismos Dominios, y sólo se hable el Castellano, como está mandado por repetidas Leyes, Reales Cédulas y Órdenes expedidas en el asunto" (Triana y Antorveza, Las lenguas indígenas, 507 y 511). Sobre el significado de la imposición del castellano como vehículo de poder, cf. Rubio, La escritura, 17, 50.

${ }^{34}$ Herrejón Peredo, Del sermón, 285, 366. 
La invasión de España por tropas napoleónica, estigmatizadas como anticlericales debido a la Revolución francesa, hizo que en varias ocasiones Lizana comenzara sus sermones considerando las "plagas" y "tribulaciones" con que Napoleón, a quien llamó el "Omnipotente", estaba afligiendo a los españoles ${ }^{35}$; y solicitara la solidaridad con España, con quien, decía en su Exhortación del 13 de septiembre de 1808, "son demasiados los vínculos que nos estrechan [...] para no tomar interés en su defensa" ${ }^{36}$. Para conseguir su propósito presentaba al pueblo los males que generaría la instrucción de un gobierno francés: “PPodría [vuestro prelado] creer que el abominable Gobierno Francés auxiliaría la Religión, respetaría los Templos y Ministros, mantendría las prácticas piadosas que nosotros conservamos?"37.

Esta misma Exhortación, que demuestra el intercambio comunicativo que había entre distintas jurisdicciones indianas, es utilizada por el cubano Manuel del Socorro Rodríguez en su periódico El Redactor Americano del Nuevo Reyno de Granada, que se redactaba en Bogotá, capital del Nuevo Reino. La situación era preocupante y se buscaba afianzar las relaciones con España, que había sido solidaria para que América avanzara hacia la ilustración, llamando a la defensa de Dios, la Patria y el Rey: "Leales Americanos: Faltaría yo a los deberes de Pastor celoso y fiel vasallo si en las críticas circunstancias que motivaron las preces públicas por la felicidad de nuestra Monarquía española omitiera instruiros sobre otros medios gratos a Dios y oportunos para conseguirla. Nadie ignora la obligación sagrada que tiene de servir a Dios, al Rey y a la Patria, considerándose afortunado en ser católico y vasallo español" ${ }^{38}$.

El sermón que predicó el 18 de agosto de 1808, "implorando el auxilio divino en las actuales ocurrencias de la Monarquía Española”, fue utilizado por el Ayuntamiento de la CDMX, quelo imprimió a sus expensas, para manifestar su adhesión a Fernando VII, a quien Lizana califica como "nuestro deseado y amado Rey". El momento político es aprovechado también para "discurrir como cristianos, señalando que la reforma moral de las costumbres puede convertirse en arma contra Napoleón, "ese tirano pérfido". El sermón entrelaza

35 Lizana y Beaumont, Sermón moral, III.

${ }^{36}$ Lizana y Beaumont, Exhortación [...] en que se manifiesta la obligación de socorrer a la nación española en la actual guerra con Francia (México (s. p. i.). [Dada el 13 de septiembre de 1808].

${ }^{37}$ Lizana y Beaumont, Exhortación [...] socorrer a la nación española.

${ }^{38}$ El Redactor Americano del Nuevo Reyno de Granada, n. ${ }^{\circ}$ 52, 19 de enero de 1809, 309. La Exhortación se traslada completa y abarca prácticamente la totalidad del número 52 del periódico (309-406), cuatro meses después de darla a conocer Lizana. 
contenidos morales con patrióticos y exalta a la nación española, uniéndola al "reino” de la Nueva España: ¿¿Por qué os parece que esta Nación, la mas noble, mas religiosa, mas leal y valerosa de todo el orbe, ha sido casi incesantemente molestada por los embidiosos de su felicidad, y codiciosos de sus riquezas y las de sus Dominios, especialmente las que la Divina Providencia quiso darle en este brillante y opulento Reyno que habitamos?"39.

Los hechos de Bayona, al ser capturado Fernando VII por Napoleón, hicieron que en la Nueva España se formaran dos partidos: uno, español, encabezado por la Audiencia, con pretensiones de mantener el statu quo que había concedido el régimen colonial; y el otro, criollo, dirigido por el Ayuntamiento, que solicitaba la formación de una Junta que se gobernara con independencia de España. El arzobispo Lizana y su primo, el inquisidor Isidoro Sainz de Alfaro y Beaumont, se adhirieron al "partido español" de la oligarquía peninsular, que reconocía la Junta de Sevilla y consideraba al virrey Pedro Garibay (1808-1809), quien gobernó después de José de Iturrigaray (1803-1808), como sujeto contrario a sus intereses por su inclinación al partido criollo.

Con el descubrimiento de una conspiración independentista el 16 de marzo de 1809, el partido español, ante la falta por parte de Garibay de reafirmar su dominio, derrocó a este del mando, y el 19 de julio tomó posesión como virrey el arzobispo Lizana, encargando a su primo Sainz de Alfaro, racionero de la Catedral, el mando de la mitra. La propaganda impresa revolucionaria comenzaba a distribuirse en las iglesias de la Ciudad de México y a colocarse en las paredes del palacio virreinal. Lizana, entonces, en septiembre de 1809 , creó un tribunal especial contra los partidarios de los franceses, llamado Junta de Seguridad y Buen Orden, y en diciembre formó las Juntas de Censura, que fueron aprobadas por las Cortes en diciembre de 1810. Su función era

${ }^{39}$ Lizana y Beaumont, Sermón que en las solemnes Rogativas que se hicieron en la Santa Iglesia Metropolitana de México implorando el auxilio divino en las actuales ocurrencias de la Monarquía Española predicó en el dia 18 de Agosto de 1808 [...] Lo da a luz la Nobilísima Ciudad de México,ylo dedica a María Santísima de Guadalupe (México: en la Oficina de Doña María Fernández de Jáuregui, calle de Santo Domingo, [s. d.-1808-], 9, 12-13, 15, 21. Este sermón es una muestra de baja calidad literaria y estructural, comparado con la mayoría de sus escritos. Tal vez, sin conocerse exactamente su fecha de impresión, fuera la del Ayuntamiento, al darlo a conocer desde su institucionalidad, una muestra de cortesía hacia los españoles y el arzobispo, una forma de relajar la tensión política del momento, que se había creado al convocar juntas el virrey Iturrigaray y, pensarse, por otro lado, la alternativa de una representación colonial ante la ausencia del soberano. En: Bravo Rubio y Pérez Iturbe, "Una iglesia”, 19. 
la de investigar las manifestaciones de apoyo a los franceses y el fermento insurreccional.

La relación e influjo de Isidoro Sainz de Alfaro sobre su primo el arzobispovirrey fue determinante en las relaciones de la Real Audiencia y el Consulado de Comercio de la capital novohispana. Intervino en los asuntos de gobierno como consejero de Lizana y alejó a los oidores destacados del anterior virrey. El gobierno de Lizana, quien en su condición de prelado había sido nombrado virrey para llamar a la concordia social en un momento de crisis, no fue del agrado del partido español (la coalición entre la Real Audiencia y los comerciantes, tanto los peninsulares como quienes se encontraban en la Nueva España),y muchos de sus miembros se manifestaron contra la supuesta preferencia que Lizana prodigó al partido criollo, aunque esta misma recriminación se dio también entre los españoles americanos ${ }^{40}$. Los miembros de la facción de Gabriel de Yermo, rico comerciante y hacendado español, quien a mitad de septiembre de 1808 dirigió el golpe de estado que derrocó al entonces virrey José de Iturrigaray, más los gremios y el consulado de comerciantes, pidieron a España en noviembre de 1809 que destituyera a Lizana. Sumado a esto, los problemas administrativos relacionados con empréstitos para atender los gastos de la guerra española, los frecuentes sucesos relativos a sublevaciones, agitaciones y conspiraciones que se dieron, el carácter benigno y conciliatorio de su gobierno, caracterizado por su debilidad; el clima, en definitiva, de tensiones, desconciertos y miedos sociales que se vivió en el momento, hicieron, una vez disuelta la Junta Central y formada la Regencia española, influenciada por los comerciantes de Cádiz, que esta lo destituyera el 8 de mayo de $1810^{41}$.

${ }^{40}$ C. G. Mejía Chávez, “'QQue le quieren dar veneno al señor arzobispo-virrey!’. Historia de una conspiración dirimida por la Inquisición de Nueva España (agosto de 1809-enero de 1810)”. HMex LXVIII, n. 1 (2018): 67. Sobre la influencia de Sainz de Alfaro en el gobierno de Lizana, ver: L. Alamán, Historia de Méjico desde sus primeros movimientos que prepararon su Independencia en el año de 1808 hasta la época presente [Edición facsimilar, 5 vol.] (México: Instituto Cultural Helénico/FCE, 1985), 303.

${ }^{41}$ Pérez Memen, El episcopado, 27-65. Una relación cuantiosa de este tipo de sucesos puede verse en M. Rivera Cambas, Los gobernantes de México. El virrey Francisco Javier de Lizana y Beaumont (México D. F.: Editorial Citlaltépetl, 1962), 5-27), y en Alamán, Historia de Méjico, 279-346. Entre agosto de 1809 y enero de 1810 , se dieron una serie de denuncias y testimonios que hablaron de una posible conjura por parte de los miembros de la Real Audiencia que planearon asesinar a Lizana por sus indebidas políticas de su gestión como virrey, algunas de ellas asociadas al gobierno del Santo Oficio y las conspiraciones de Valladolid (1809) y de Querétaro (1810). Una conjura dirigida supuestamente por el oidor Guillermo de Aguirre 
Su corto mandato se distinguió principalmente por la defensa de la Nueva España de la amenaza de la propaganda francesa y por sus actitudes suspicaces ante las facciones de la Audiencia. Mientras la lealtad de los mexicanos a la Corona se iba minando, sus proclamas hablaban al pueblo de hermandad, de unidad y de obligaciones religiosas. En su primera proclama como virrey se presenta, en nombre de Fernando VII, con la distinción de "padre" para dar cuenta de ser su representante directo en la Nueva España: "Erais en cierto modo todos hijos míos en Jesucristo; ya desde hoy seré propiamente, en nombre del rey, vuestro padre. Sí; éste nombre entre los muchos que corresponden a la dignidad y oficio de virrey, es el que adopto para con vosotros todos, mientras maneje las riendas que he tomado". En contra de José Bonaparte, apela a la unión de los "españoles americanos", donde parece incluir tanto a gachupines como a criollos, diciendo que su sangre "no degenera por haber atravesado el océano; ella no pierde en América su espíritu y energía”. Busca en realidad el apoyo de todos los ministros de la Audiencia, de los militares y el clero y, sintiéndose "débil, enfermo y agobiado del peso de la mitra", su propuesta de gobierno es la de procurar por la "felicidad [...] con el fomento de las ciencias y de la policía, de la agricultura y de las artes, del comercio y de las minas" ${ }^{2}$.

Lizana siguió mostrando adhesión a la Corona después de su destitución como virrey y así lo expone en su carta pastoral del 8 de julio de 1810 ("exhortaremos, y mandaremos la sumisión, obediencia, y fidelidad á nuestro amado, escogido y jurado solemnemente por rey de España é Indias Fernando VII"). Siguió proclamando los principios de fidelidad a Dios, al Rey y a la Patria, siempre con la prevención del "escudo de la fe" y contra Napoleón, para quien cada vez se hacían más duras sus palabras: "ese diablo malo, que ha vomitado el infierno para seducir, si es posible, como otro Anticristo, a los mas fieles y leales vasallos [...] ese monstruo, depositario verdadero de la infelicidad, de

en complicidad con destacados políticos y comerciantes de la Ciudad de México, en la que también se vio involucrado Juan López de Cancelada, entonces editor de la Gazeta de México y vocero de los españoles resentidos con el arzobispo-virrey, y quien llegó a opinar sobre la influencia de la élite criolla en Lizana, diciendo que esta era tal que lo convencieron de que los "gachupines" ("españoles nacidos en Europa") intentaban deponerlo del cargo, así como lo hicieron con Iturrigaray. En marzo de 1810, por orden del prelado, el editor fue expulsado a España. Ver: Mejía Chávez, “'Que le quieren dar veneno...”, HMex LXVIII, 1: 49-110.

${ }^{42}$ Lizana y Beaumont, "Habitantes de la Nueva España”, proclama del 22 de julio de 1809 , en Colección de documentos para la historia de la Guerra de Independencia de México, Tomo I, ed. J. E. Hernández Dávalos [Dirección Virginia Guedea y Alfredo Ávila] (México D. F.: Universidad Autónoma de México, 2007). 
este sacrílego, que varias veces se ha atrevido a blasfemar e insultar el nombre santo de Dios".

Los horrores de la ocupación francesa son expuestos con un modélico estilo formal que utiliza la amplificatio en un amplio listado de desgracias o calamidades que van aumentando el sentido negativo de su contenido:

Robos, defloraciones de doncellas y religiosas, violencias de casadas y viudas, asesinato de sacerdotes, de párvulos y de ancianos; incendios y saqueos de casas, de pueblos, de campos e Iglesias; búrlas, mofas, y prisiones de todos; escarnios de los venerables Reliquias é Imágenes de los Santos, de María Santísima, y de Jesucristo, y también; pero aquí tiemblo, Desprecios y vexaciones en los augustos sagrarios y real presencia de Jesús en el adorable Sacramento del Altar, arrojando las santas formas por los suelos, y saliendo por las calles de Cuenca con el Copon en aquellas detestables manos gritando así: ¿quién compra á Dios? ${ }^{43}$.

Dos años después de la invasión francesa se presentó para la Corona española el problema de la insurgencia. En un primer momento, ante las conspiraciones que se dieron en Valladolid, y frente al tono más enérgico como el de su primo Sainz de Alfaro o el del obispo de Valladolid (Michoacán), Manuel Abad y Quipo, a comienzo de 1810 Lizana los califica de "leves acontecimientos y rumores de desavenencias privadas". No encuentra en ellos, dice,

[El] carácter de malignidad que los poco instruidos han querido darles; pues ellos no han nacido de otro origen que o la mala inteligencia de algunas opiniones relativas al éxito de los sucesos en España o de falsas imposturas en las que se ha desahogado el resentimiento personal.

El asunto, en realidad, parece ligarlo a las diferencias que entre "criollos" (españoles nacidos en América) y "gachupines” (españoles nacidos en Europa) comenzaban a sentirse con intensidad. No basta con desechar el temor a Napoleón, dice, y es indispensable "estar unidos y hermanados", pues estas diferencias son "una simiente de emulaciones, envidias, resentimientos, y aún de odio y de diversidad de opiniones en orden a la causa pública” y, según el arzobispo, estas denominaciones "jamás han merecido distinción para el

${ }^{43}$ Lizana y Beaumont, Carta pastoral [dirigida] a sus fieles súbditos sobre la falsedad de las promesas de Napoleon y su hermano Josef [Dada en México a 8 de julio de 1810], 4-5, 10, 12). 
aprecio, los empleos y los honores, ni en la consideración de las leyes, ni en el ánimo de los monarcas" ${ }^{4}$.

Abad y Queipo publicó el 24 de septiembre de 1810 un edicto de excomunión contra el cura Miguel Hidalgo del cual se puso en duda su oficialidad. Lizana, de nuevo en sus funciones arzobispales, dio validez al decreto y presentó una imagen negativa de Hidalgo ante sus feligreses con el fin de extinguir el movimiento insurgente. Hidalgo publicó en Guadalajara un decreto que ordenaba que las tierras de comunidad de los pueblos fueran cultivadas exclusivamente por los indios. Lizana, cuando ya la insurrección se había fortalecido y la oratoria sagrada utilizaba términos como los de “insubordinación” y "rebeldía”, presentó al cura de Dolores como hereje y cismático, sedicioso e ingrato; alguien que se levantó contra el altar y el trono y, por tanto, era merecedor de excomunión mayor. Utilizando el Antiguo Testamento, lo compara con Luzbel: "tú que lucías como un astro brillante por tu ciencia, ¿cómo has caído como otro Luzbel por tu soberbia? ¡Miserable! [...] No esperes que mis ángeles (así llama la Escritura a los sacerdotes) vayan tras de ti [...] Todos pelearán con el propósito de la milicia eclesiástica, y no se volverá a oír tu nombre en este reino de Dios, sino para eternos anatemas".

Exponía a sus diocesanos que el proyecto de los insurgentes era contrario a la "ley y doctrina de Jesucristo", pues inspiraba odio contra el prójimo. Para persuadirlos utilizaba la concepción de los premios y castigos de la ética cristiana y, así, si se observaba el precepto de amar al prójimo se podría ir al cielo, pero si se seguía el camino de los "revolucionarios", este conduciría al "infierno" . En contra de las divisiones políticas, con el empleo de metáforas religiosas ("Cristo no está dividido"), recuerda su periodo como virrey, cuando "os hablé de la pueril rivalidad y necios partidos de europeos y criollos". Tratando a Hidalgo de "precursor del anticristo", apela a los "deberes de hombre civil" y a la unidad de la América hispana, cuando dice que el "demonio" se "ha aparecido en nuestra América para perderos" 45 .

Los obispos de la Iglesia novohispana declararon, en esta fase inicial de la Independencia, su hispanofilia y exhortaron a los insurgentes a deponer las armas, identificando la causa religiosa con la causa política en oposición al liberalismo, que se había relacionado con los ideales de la Revolución francesa.

${ }^{44}$ Lizana y Beaumont, Proclama del arzobispo virrey de Nueva España a los fieles vasallos de Fernando VII (s. p. i, 23 de enero de 1810), 8, 12.

${ }^{45}$ Lizana y Beaumont, Exhortación a sus fieles y demás habitantes de este reyno (México: en la Oficina de Don Mariano de Zúñiga y Ontiveros, 24 de septiembre de 1810), 2, 4. 
Creyeron que la crisis española podría cambiar el sentido religioso de sus feligreses y procuraron afirmar y sostener en sus discursos y acciones los valores tradicionales que implicaba la tríada Religión, Patria y Rey.

Las virtudes religiosas, militares e intelectuales de la imagen del rey español se vieron fortalecidas por la coyuntura de 1808. La defensa dela monarquía se enfocó en dos hechos operativos: la realización de actos religiosos y la invocación a los fieles a apoyar económicamente a los ejércitos españoles enfrentados a los franceses. La Iglesia invitaba a los feligreses a reconocer a la Corona española como gobierno legítimo ${ }^{46}$ :

No reconoceremos otro soberano, que al que tiene el sagrado de las leyes, y los votos de toda la monarquía, y que con toda justicia se debe negar esta fiel América á reconocer al intruso déspota. Nos mantendremos con todas nuestras ovejas y súbditos, firmes en defender, que es nulo y violento quanto se maquinó en Bayona por malvado retrato de Asúr ${ }^{47}$.

La proclama de excomunión para los partidiarios de la insurrección se generalizó entre el clero y se sucedieron medidas dirigidas a restablecer la quietud y la paz de los mexicanos. Lizana cerró el periodo de esplendor de la Iglesia colonial, cuando ya desde mediados del siglo XVIII había comenzado a debilitarse la incidencia de la jurisdicción episcopal. Desde que se implantaron las reformas borbónicas con el objeto de sanar la crisis fiscal, se desataron conflictos sobre las competencias entre gobernantes civiles y religiosos en todos sus niveles, pues el objetivo de la Corona fue supeditar la marcha social a las decisiones del gobierno civil ${ }^{48}$. La "religiosidad barroca" heredada del siglo anterior se encontraba enraizada en las masas, pero ya no encontraba el mismo apoyo que antes entre las élites eclesiásticas. La tradición religiosa fue atacada en la época colonial tardía y mientras la Real Audiencia de México lo hacía, Lizana y Beaumont, como otros representantes del alto clero, propuso una reforma de las prácticas de la piedad popular y se preocupó por la preparación doctrinal y espiritual de los sacerdotes.

46 J. D. Cortés Guerrero, "La lealtad al monarca español en el discurso político religioso en el Nuevo Reino de Granada", Anuario Colombiano de Historia Social y de la Cultura 31, n. ${ }^{1}$ (2010): 43, 83. 50.

${ }^{47}$ Lizana y Beaumont, Carta pastoral sobre la falsedad, 12.

${ }^{48}$ W. B. Taylor, Ministros de lo sagrado. Sacerdotes y feligreses en el México del siglo XVIII (México D. F.: El Colegio de México/Secretaría de Gobernación/El Colegio de Michoacán, 1999). 
El arzobispo-virrey coincidió con las ideas del obispo ilustrado Manuel Abad y Quipo, para quien la Iglesia estaba dentro del Estado y por ello debía contribuir a la sociedad civil fomentando los intereses económicos y educativos. Pero para el obispo, la degradación del clero, que había supuesto la legislación emitida por la Real Audiencia referente al fuero eclesiástico, perjudicaba al bien público y hacía peligrar los intereses de la monarquía, pues los ministros de la Iglesia eran, decía, los "verdaderos custodios de las leyes y los garantes de su observancia" ${ }^{49}$. En el mismo sentido, el arzobispo Lizana denunció la excesiva secularización de religiosos y una moral cristiana que consideró relajada. $\mathrm{Su}$ patriotismo no fue motivo de crítica por parte de las élites criollas, pero su defensa y fidelidad "al religioso y solemne juramento, y a las leyes del gobierno español"50, en un momento en que se desmoronaba el imperio español, suponía el reconocimiento de que la soberanía de la monarquía católica solo podía justificarse y sostenerse desde la defensa de la religión.

Para exhortar al cumplimiento de las leyes del gobierno español y a la obediencia a un mismo "rey de España e Indias", Lizana apelaba a partir de septiembre de 1808 a unos "Leales Americanos" y a "esta fiel América", pero ya a mitad de julio de 1810, cuando habla así, de una "fiel América", las exclamaciones de amor con que frecuentemente se había dirigido al " $\mathrm{OOh}$ México mío!", a la "Ciudad mía muy amada de México"51 , cambian de tono y se revisten de un carácter social; parecen dejar la puerta abierta a un sentimiento de nacionalidad que va más allá de una simple fidelidad y que nunca, no obstante, podría desligarse de lo religioso: "Seamos finalmente, siempre americanos, que es lo mismo que decir, religiosos, devotos, fieles, constantes y siempre agradecidos á la divina providencia" 52 . "Siempre americanos", una expresión cercana al criollismo cuyas bases sociales incluían a la pequeña burguesía, generadora del sentido protonacionalista que los llevó a comprender

${ }^{49}$ B. F. Connaughton, Dimensiones de la identidad patriótica. Religión, política y regiones en México. Siglo XIX (México D. F.: Universidad Autónoma Metropolitana, Unidad Iztapalapa, 2001), 13-14.

${ }^{50}$ Lizana y Beaumont, Carta pastoral sobre la falsedad, 13-14.

${ }^{51}$ Lizana y Beaumont, Carta Pastoral [dirigida] a todos los Fieles de su Arzobispado con ocasión de las calamidades de España (México: por Don Mariano de Zúñiga y Ontíveros, calle del Espíritu Santo, año de 1805), 7, 10.

${ }^{52}$ Lizana y Beaumont, Carta pastoral sobre la falsedad, 12, 15. 
que no eran sencillamente españoles que vivían y buscaban un futuro estable en América, sino americanos ${ }^{53}$

De este discurso, generalmente patriótico, que se generalizó en los púlpitos mientras duró la crisis española, se pasó al discurso cívico. Es un periodo que inicia en la tercera década del XIX y se prolonga hasta mucho después. Convivía con el sermón panegírico y el moral, y puede a su vez contener diversas formas, desde las oraciones retóricas que celebran la Independencia u otros acontecimientos nacionales, hasta la exhortación sobre los valores de la ciudadanía, que fundamentalmente quedarán representados en una nueva legislación ${ }^{54}$.

La invasión napoleónica, las Cortes de Cádiz y la Independencia mexicana trajeron consigo un auge en la impresión de la folletería. De bajo precio y fácil circulación (los folletos se pueden transmitir de mano en mano), su corta extensión potencia la adopción de diversos estilos literarios, desde los más solemnes hasta los más humorísticos; estaban destinados a remover conciencias y mezclaban un lenguaje culto con otro popular; la emotividad y la imaginación con apelaciones a la razón. Una folletería oficial, en la que podían incluirse sermones en honor a santos, las oraciones cívicas por fiestas patrias $\mathrm{y}$ los escritos dedicados a episodios sobre insurrecciones o guerras civiles; $\mathrm{y}$ una folletería no oficial ocupada en la opinión de ciertos sucesos y dispositivos legislativos que el gobierno emitía. Principios políticos, asuntos judiciales, preceptos religiosos, temas educativos, avances científicos, novedades económicas, o ensayos literarios fueron cuestiones, entre otras, que sobre todo a partir de la Independencia mexicana recogió la folletería pública que, por otro lado, fue un medio útil para denunciar o defender a personas e instituciones.

Los folletos se hicieron vehículo cotidiano de la discusión pública en el tránsito de la cultura política hacia un mayor encuentro con la ciudadanía. El clero, después de la época colonial, supo acoplarse al nuevo rumbo del país; y las oraciones cívicas, frente a la exhaltación delcumplimiento de objetivos transcendentales que había publicitado la mayor austeridad con que se revestían los sermones y cartas pastorales del periodo anterior en el que el arzobispo Lizana había desarrollado una cuantiosa producción escrituraria, trataban

${ }^{53}$ Cf. T. E. Anna, La caída del gobierno español en la ciudad de México (México D. F.: FCE, 1978).

${ }^{54}$ Cf. Herrejón Peredo, Del sermón, 285, 366. 
de buscar, desde distintas posturas ideológicas, "una moral unificadora de la ciudadanía" con pretensiones de enlazarla al servicio de los proyectos patrios $^{55}$

\section{Conclusiones}

Los escritos de Francisco Xavier de Lizana y Beaumont, mayoritariamente en forma de carta pastoral, entrelazan la práctica de la escolástica tradicional, ajustada a la intertextualidad de la Biblia y de las obras de los Padres de la Iglesia, citadas frecuentemente en latín, con la prédica que aplica los tropos retóricos de forma erudita y elocuente. A través de un estilo propio, permiten conocer sus intenciones programáticas que, bajo una transmisión de valores y virtudes cristianas, intentan encasillar al sujeto en un modelo ideal de comportamiento para conformar un cuerpo social acorde con los objetivos de una determinada política colonizadora a cuya evolución se van adaptando.

La Ilustración católica llevó a buscar un cristianismo más puro y auténtico. Las actitudes morales fueron mayor preocupación que los dogmas teológicos. La necesidad de hacer sentir que la fe católica provenía de las virtudes naturales del hombre hizo considerar a los santos como "héroes del cristianismo" con virtudes más morales que teologales.

La tríada Dios (Religión), Patria y Rey fue inseparable en la defensa de la corona española. La lealtad por parte de los americanos al monarca puede considerarse como un gesto a favor de la igualdad con los españoles peninsulares en unos momentos en los que, al mismo tiempo, algunos sectores sociales insistían en romper con España; un deseo, no obstante, que después de la constitución de 1812, en ocasiones interrumpido, pasó a ser explícito.

En México hubo distintos discursos políticos clericales durante las dos primeras décadas del siglo XIX y estos se desplegaron por todas sus regiones a través de cartas pastorales, sermones, oraciones cívicas, periódicos y folletos. Fue una producción de fuerte carácter ideológico y se situaba frente a las nuevas coordenadas del pensamiento político. Mediante la difusión del

${ }^{55}$ Cf. B. F., Connaughton, Entre la voz de Dios y el llamado de la patria. Religión, identidad y ciudadanía en México, siglo XIX (México D. F.: Universidad Autónoma Metropolitana/Fondo de Cultura Económica, 2010), 84, 96 y L. B. Suárez de La Torre, “De la devoción al interés político”, Secuencia 39 (1997): 61,72. Esta autora, al analizar la producción eclesiástica en el periodo que va de 1837 a 1851, encuentra múltiples modalidades tipológicas y temáticas en los folletos: los novenarios, los triduos y los quinarios, las oraciones específicas para cada santo, los sermones marianos, las constituciones y reglas de las diversas congregaciones, las cartas pastorales, las órdenes religiosas, la teología y puntos de doctrina, los catecismos, los informes y circulares, los edictos y las noticias parroquiales. 
dogma cristiano y unos valores y una sensibilidad religiosa, las cartas pastorales de Lizana demuestran una preocupación constante por mantener y hacer mantener la fidelidad a un programa político patriótico.

En los casi siete años que duró su estancia mexicana, Lizana partió de un discurso de estricto adoctrinamiento religioso que enseguida comenzó a participar de las políticas ilustradas. La formación espiritual en los sacerdotes, la práctica de las virtudes frente a los vicios, las condiciones sociales de la población, el adoctrinamiento de los indígenas, el principio de la utilidad relacionado con la educación cívica, la unificación lingüística fueronintereses manifestados por el arzobispo que, si bien pueden enmarcarse en el nuevo papel de la Corona y en la sensibilidad social de la época, también reflejan, bajo un componente de arraigada tradición cristiana, un rígido conservadurismo moral. El ataque a los "desarreglos" que origina la práctica del juego, el "provocativo" decoro de las mujeres, así como otros considerados "perjudiciales vicios”, demuestran que todavía se vivía en un ambiente cultural en el cual la religión no solo era entendida como culto y creencias, sino como un medio de comunicación formador de conciencias que, al lado, de la esfera civil o, influyendo en ella, poseía una destacada autoridad.

La crisis de la monarquía hispana en América hizo que la oratoria sagrada centrara sus asuntos en el campo político, en defensa de ella y en contra de los intereses expansivos de Napoleón. En Lizana esto se hace evidente y se radicaliza (en contra de Napoleón y en contra también de la insurgencia naciente) durante su periodo de proclamas virreinales. Pero aun así, nunca se abandonó el factor religioso y, por medio de él, la participación clerical, con un sentido discursivo más relevante en los hechos políticos, contribuyó al surgimiento de la nacionalidad. 


\section{Referencias bibliográficas}

\section{Fuentes primarias}

\section{Pastorales, exhortaciones, instrucciones y sermones de Francisco Xavier de Lizana y Beaumont}

Lizana y Beaumont, Francisco Xavier. Carta pastoral, que el Ilustrísimo Señor Doctor

Francisco Xavier de Lizana y Beaumont Arzobispo de México, del Consejo de Su Magestad, etc., dirige a los fieles de su Arzobispado sobre Grandeza de nuestra Santa Religión, en lo que enseña, manda creer y practicar. México: Imprenta Madrileña de la Calle de Santo Domingo, y Esquina de Tacuba, año de 1803.

Carta pastoral [dirigida] a sus diocesanos con el fin de exhortarlos y prepararlos para unos Exercicios espirituales públicos. México: por D. Mariano de Zúñiga y Ontiveros, calle del Espíritu Santo, año de 1804.

Carta Pastoral en la que [...] Instruye a sus súbditos sobre los desengaños y frutos que han debido sacar de los Exercicios espirituales que acaban de practicar. México: por D. Mariano de Zúñiga y Ontiveros, calle del Espíritu Santo, año de 1804. Carta Pastoral en la que [...] Instruye a los fieles sobre el juego y los desarreglos que en él se hallan. México: en la Imprenta de D. Mariano de Zúñiga y Ontiveros, año de 1804.

Carta Pastoral [dirigida] a todos los Fieles de su Arzobispado con ocasión de las calamidades de España. México: por Don Mariano de Zúñiga y Ontíveros, calle del Espíritu Santo, año de 1805.

Carta pastoral [dirigida] a su clero sobre la santidad del estado Sacerdotal y obligacionesinseparables de él. México: Oficina de la calle de Santo Domingo, 1807. Exhortación [dirigida] a los Conventos de Religiosas de su Filiación. Sobre algunas preocupaciones opuestas a la puntual observancia de sus deberes. México: en la Oficina de Doña María Fernández de Jáuregui. Calle de Santo Domingo, año de 1808 .

Sermón moral que en la solemne acción de gracias, que se hace anualmente en el Sagrario de esta Santa Iglesia Metropolitana de México por los beneficios recibidos de la Divina Piedad, predicó la noche del día 31 de Diciembre de 1805 el Ilustrísimo Señor Don Francisco Xavier de Lizana y Beaumont, Arzobispo de dicha Santa Iglesia. México: en la oficina de Doña María Fernández Jáuregui, calle de Santo Domingo, año de 1806.

Exhortación [...] en que se manifiesta la obligación de socorrer a la nación española en la actual guerra con Francia. México (s. p. i.), [Dada el 13 de septiembre de 1808].

Sermón que en las solemnes Rogativas que se hicieron en la Santa Iglesia Metropolitana de México implorando el auxilio divino en las actuales ocurrencias de la Monarquía Española predicó en el dia 18 de Agosto de 1808 [...] Lo da a luz la Nobilísima 
Ciudad de México, y lo dedica a María Santísima de Guadalupe. México: en la Oficina de Doña María Fernández de Jáuregui, calle de Santo Domingo, [s. d. -1808-]. Instrucción pastoral [...] sobre la costumbre de llevar las Señoras el pechoy brazos desnudos. México: en la oficina de Doña María Fernández de Jáuregui, calle de Santo Domingo. Año de 1808.

Habitantes de la Nueva España, proclama del 22 de julio de 1809. En

Colección de documentos para la historia de la Guerra de Independencia de México,

Tomo I, ed. J. E. Hernández Dávalos [Dirección de Virginia Guedea y Alfredo Ávila]. México D. F.: Universidad Autónoma de México, 2007.

Proclama del arzobispo virrey de Nueva España a los fieles vasallos de Fernando VII (s. p. i.), 23 de enero de 1810.

Carta pastoral [dirigida] a sus fieles súbditos sobre la falsedad de las promesas de Napoleon y su hermano Josef. [Dada en México a 8 de julio de 1810 años]. . Exhortación a sus fieles y demás habitantes de este reyno. México: en la Oficina de Don Mariano de Zúñiga y Ontiveros, 24 de septiembre de 1810.

\section{Archivo}

Archivo Parroquial de Arnedo (La Rioja, España), Libro de Bautizados de la Parroquia de Santo Tomás, año de 1749.

\section{Publicaciones periódicas}

Gaceta de México (Ciudad de México), 11 de febrero de 1803.

El Redactor Americano del Nuevo Reyno de Granada (Bogotá), n.o 52, 19 de enero de 1809.

\section{Fuentes secundarias}

Alamán, L. Historia de Méjico desde sus primeros movimientos que prepararon su Independencia en el año de 1808 hasta la época presente [edición facsimilar, 5 vols.] México: Instituto Cultural Helénico/FCE, 1985.

Alcalá y Orozco, J. M. de. Elogio fúnebre del Excelentísimo e Ilustrísimo Señor Don Francisco Xavier de Lizana y Beaumont, Prelado, Gran Cruz del Orden de Carlos III, Virrey y Arzobispo de México. México: en la Imprenta de Doña María Fernández de Jáuregui, 1813.

Anna, T. E. La caída del gobierno español en la ciudad de México. México D. F.: FCE, 1978.

Bravo Rubio, B. y M. A. Pérez Iturbe. "Una iglesia en busca de su independencia: el clero secular del Arzobispado de México, 1803-1822”. Tesis del Título de Licenciado en Historia, Universidad Nacional Autónoma de México, 2001.

Brigs, A. y P. Burke. De Gutenberg a Internet. Una historia social de los medios de comunicación. Madrid: Taurus/Santillana, 2001.

Chinchilla Pawling, P. De la “compositio loci” a la república de lasletras. Predicaciónjesuita en el siglo XVII novohispano. México D. F.: Universidad Iberoamericana, 2004. 
Connaughton, B. F. Dimensiones de la identidad patriótica. Religión, política y regiones en México. Siglo XIX. México D. F.: Universidad Autónoma Metropolitana. Unidad Iztapalapa, 2001.

Connaughton, B. F. Entre la voz de Dios y el llamado de la patria. Religión, identidady ciudadanía en México, siglo XIX. México D. F.: Universidad Autónoma Metropolitana/Fondo de Cultura Económica, 2010.

Connaughton, B. F. “Transiciones en la cultura político/religiosa mexicana, siglo XVII. 1860: El aguijón de la economía política”. En: Poder civil y catolicismo en México, siglos XVI al XIX, editado por F. J. Cervantes Bello, A. Tecuanhuey Sandoval y M. P. Martínez López-Cano, 447-466. México D. F.: Benemérita Universidad Autónoma de Puebla -Instituto de Ciencias Sociales y Humanidades "Alfonso Vélez Pliego"-/Universidad Nacional Autónoma de México -Instituto de Investigaciones Históricas-, 2008.https://www.historicas.unam.mx/publicaciones/ publicadigital/libros/podercivil/pcivil020.pdf

Cortés Guerrero, J. D. “La lealtad al monarca español en el discurso político religioso en el Nuevo Reino de Granada”. Anuario Colombiano de Historia Social y de la Cultura n⿳⺈⿴囗十一 Vol. 37, № 1 (2010): 43-83.

Domínguez Ortiz, A. Carlos III y la España de la Ilustración. Madrid: Alianza, 2016.

Hernández Dávalos, J. E., ed. Colección de documentos para la Historia de la Guerra de Independencia de México, Tomo I [Dirección de Virginia Guedea y Alfredo Ávila]. México D. F.: Universidad Autónoma de México, 2001.

Herrejón Peredo, C. Del sermón al discurso cívico: México, 1760-1834. México D. F.: El Colegio de Michoacán/ El Colegio de México, 2003.

Herrero Salgado, F. La oratoria sagrada española de los siglos XVI y XVII. Madrid: Fundación Universitaria Española, 1993.

Jiménez Rodríguez, M. 2017. “La emoción como estrategia argumentativa en el mitin español”. Discurso \& Sociedad Vol.11, № 4 (2017): 621-641.

Laan, C. G. "La moral cristiana en las cartas pastorales de san Pablo”. Tesis Doctoral, Facultad de Teología, Universidad de Navarra (Pamplona), 1999: 25-90.https:// dadun.unav.edu/bitstream/10171/11586/1/CDT_XXXVI_01.pdf

Mejía Chávez, C. G. “'¿Que le quieren dar veneno al señor arzobispo-virrey!'. Historia de una conspiración dirimida por la Inquisición de Nueva España (agosto de 1809-enero de 1810)”. HMex LXVIII, № 1 (2018): 49-110.

Mörner, Magnus. La Corona española y los foráneos en los pueblos de indios de América. Estocolmo: Almqvist y Wiksell, 1970.

Pérez Memen, F. El episcopado y la Independencia de México (1810-1836). México D. F.: Editorial JUS, 1977.

Rivera Cambas, M. Los gobernantes de México. El virrey Francisco Javier de Lizana y Beaumont. México D. F.: Editorial Citlaltépetl, 1962.

Rodríguez Casado, V. “Iglesia y Estado en el Reinado de Carlos III”. Estudios Americanos Vol.1, № 1 (1948): 5-57. 
Rubio, A. La escritura del archivo. Recurso simbólico y poder práctico en el Nuevo Reino de Granada. Santiago de Cali: Universidad del Valle / Facultad de Humanidades / Departamento de Historia, 2014.

Silva, R. "El sermón como forma de comunicación y como estrategia de movilización. Nuevo Reino de Granada a principio del siglo XVII". Sociedad y Economía, №. 1 (2001): 103-130.

Suárez de La Torre, L. B. “De la devoción al interés político”. Secuencia 39 (1997): 61-72.

Taylor, W. B. Ministros de lo sagrado. Sacerdotes y feligreses en el México del siglo XVIII. México D. F.: El Colegio de México/Secretaría de Gobernación/El Colegio de Michoacán, 1999.

Triana y Antorveza, H. Las lenguas indígenas en la historia social del Nuevo Reino de Granada. Bogotá: Instituto Caro y Cuervo, 1987. 